\title{
The discovery of Barretonus (Curculionidae: Cossoninae) in the Canary Islands: barcoding, morphology and description of new species
}

\author{
Rafael GARCÍA ${ }^{1, *}$, Carmelo ANDÚJAR ${ }^{2, *}$, Pedro OROMÍ ${ }^{3)}$, Brent EMERSON ${ }^{2)} \&$ Heriberto LÓPEZ ${ }^{2)}$ \\ 1) C/. San Miguel 9, 38700 Santa Cruz de La Palma, La Palma, Canary Islands; e-mail: rgarbec@gmail.com \\ ${ }^{2)}$ Island Ecology and Evolution Research Group, Instituto de Productos Naturales y Agrobiología, 38206 La Laguna, Tenerife, Canary Islands; e- \\ mails: candujar@ipna.csic.es, bemerson@ipna.csic.es, herilope@ipna.csic.es (corresponding autor) \\ ${ }^{3)}$ Depto. Biología Animal, Universidad de La Laguna, 38206 La Laguna, Tenerife, Canary Islands; e-mail: poromi@ull.es \\ *) joint first authors
}

Accepted:
$19^{\text {th }}$ July 2019
Published online:
$16^{\text {th }}$ August 2019

Zoobank: http://zoobank.org/urn:lsid:zoobank.org:pub:21A58238-EE1B-42E9-B3F2-23BF15649502

(C) 2019 The Authors. This work is licensed under the Creative Commons Attribution-NonCommercial-NoDerivs 3.0 Licence.

\begin{abstract}
The genus Barretonus Roudier, 1958 is a genus endemic to Macaronesia, described from the archipelago of Madeira where four species are known to date. In this study, two new species of Barretonus, B. auarita García \& Oromí sp. nov. (from La Palma, Canary Islands) and $B$. daute García \& Andújar sp. nov. (from Tenerife, Canary Islands), are described based on morphological and molecular evidence ( $m t C O I)$, and additional notes on their biology and ecology are provided. Morphology of the new species is compared with the other representatives of the genus, and their phylogenetic relationships with a Barretonus representative from Madeira and species from additional genera within the Cossoninae are shown. This work increases the number of species of the genus Barretonus from four to six anophthalmous or microphthalmous species with an endogean lifestyle, and incorporates the Canary Islands into its Macaronesian range of distribution.
\end{abstract}

Resumen. El género Barretonus Roudier, 1958 es un género endémico de la Macaronesia, compuesto por cuatro especies descritas del archipiélago de Madeira. En este estudio se describen dos nuevas especies de Barretonus, B. auarita García \& Oromí sp. nov. (La Palma, Islas Canarias) y B. daute García \& Andújar sp. nov. (Tenerife, Islas Canarias), en base a evidencias morfológicas y moleculares ( $m t C O I)$, y se aportan algunas notas adicionales sobre su biología y ecología. La morfología de las nuevas especies es comparada con la de los otros representantes del género, y se muestran sus relaciones filogenéticas con una especie de Barretonus de Madeira y varias especies de otros géneros de Cossoninae. Este trabajo incrementa de cuatro a seis el número de especies del género Barretonus, todas ellas anoftalmas o microftalmas con un tipo de vida endogeo, e incorpora las Islas Canarias a su rango de distribución macaronésico.

Key words. Coleoptera, Curculionidae, Cossoninae, Barretonus, new species, DNA barcoding, endogean, Canary Islands, Macaronesia, Palaearctic Region

\section{Introduction}

The weevil genus Barretonus, belonging to the tribe Dryotribini, was described by Roudier (1958) based on specimens collected from Deserta Grande, an island in the Madeira archipelago. To date, four endemic anophthalmous or microphthalmous species are known from this archipelago: B. desertae Roudier, 1958 described from four specimens collected in decaying wood (Deserta Grande); B. minor Folwaczny, 1972 described from a single specimen collected at Pico do Castelo (Porto Santo); B. major Folwaczny, 1972 described from a female collected by sifting remains of roots and stems of succulent plants (Ilhéu Chão, Desertas); and B. hinterseheri Folwaczny, 1975 described from four specimens 
collected in damp rotting wood (Funchal, Madeira). At first sight, Barretonus resembles Pseudophloeophagus Wollaston, 1873, another Cossoninae genus also present in Madeira. However, morphological characters (absence of marked humeri and humeral callus, well-marked metathoracic suture), point to a closer relationship with Leipommata Wollaston, 1857, another Macaronesian genus that includes two species, one from Porto Santo and another from the Selvagens Islands (Osella 1978). ROUDIER (1958) lists a series of morphological characters that differentiate Barretonus from Leipommata: (i) shiny elytra with punctured striae without long hairs in Barretonus compared to mat, grainy tegument with long erected hairs in Leipommata; (ii) anterior tibiae normal in Barretonus compared to tibiae heavily expanded at apex, with a highly developed internal hook in Leipommata; (iii) the central part of the mesoventrite clearly narrower in Leipommata; and (iv) the prosternal process slightly inclined in Barretonus but steep in Leipommata.

The species of Barretonus from the Madeira archipelago have an endogean (i.e. soil-dwelling) lifestyle. They are generally found buried deep in the mulch of particular plant species (Crithmum maritimum, Cynara cardunculus, Ficus carica, Euphorbia piscatoria), associated with their litter or dead roots. They have also been found inside half buried rotten wood (STÜBEN 2018). These habitat requirements complicate the sampling of these weevils by direct observation, and targeted techniques such as use of sifter, Winkler or Berlese devices are needed to capture them. In many cases soil washing must be adopted. When studying the material sampled from soil at two localities in La Palma and two in Tenerife (Canary Islands), we found a series of anophthalmous Barretonus; this is the first record of the genus from the Canary Islands and extends the distribution of the genus within the Macaronesian region.

The purpose of the present work is to describe two new Canarian Barretonus species based on morphological and molecular evidence.

\section{Material and methods}

Depositories. The material examined is deposited in the following collections:

AMC Antonio Machado personal collection, Canary Islands, Spain;

CAF Carmelo Andújar Fernández personal collection, Canary Islands, Spain;

HLH Heriberto López Hernández personal collection, Canary Islands, Spain;

IPNA-CSIC Invertebrates collection of the Instituto de Productos Naturales y Agrobiología, La Laguna, Spain;

JK Jiří Kratký personal collection, Hradec Králové, Czech Republic;

MCNT Museum of Natural Sciences of Tenerife, Canary Islands, Spain;

MNCN National Museum of Natural Sciences, Madrid, Spain;

POM Pedro Oromí Masoliver personal collection, Canary Islands, Spain;

PS Peter Stüben personal collection, Mönchengladbach, Germany;

RGB Rafael García Becerra personal collection, Canary Islands, Spain.
Sampling and imaging. Specimens collected on La Palma were found by sifting litter and roots of coastal plants or by direct examination inside the dead roots. This material includes 41 specimens collected from recurrent samplings in Juan Adalid in the north of the island, and three additional specimens collected at Playa Nogales, in the northeast of the island. Almost all specimens collected on Tenerife were obtained by soil washing, samples were taken in the thermophilous forest patch at Los Silos, following the technique described by ArRiBAs et al. (2016). One additional specimen was collected in the same area by sifting leaf litter within a thermophilous forest patch at Interián.

For a comparative morphological analysis with respect to other Barretonus species, several specimens of $B$. desertae, $B$. minor, and $B$. hinterseheri from the collection of Peter Stüben were used. Examination, dissection, measurement, and drawings were completed using a Carl Zeiss Citoval 2 stereomicroscope with an ocular micrometer. Photographs of the Canary Islands species were taken using a CanonPowershot A650 attached to a Zeiss Stemi 2000 stereomicroscope, and processed with Zerene Stacker (V. 1.04, Zerene Systems, LLC., Richland, WA), with images combined into a single image using pmax and dmap methods.

DNA extraction, PCR amplification and sequencing. Sequences of the 5' end of the cytochrome c oxidase subunit I (COI), a DNA fragment considered the standard DNA barcode region for Metazoa (HEBERT et al. 2003), have been generated for five specimens of Barretonus from Los Silos (Tenerife), one from Juan Adalid (La Palma) and one from Playa Nogales (La Palma) (see Table 1 for sequence accession numbers). Genomic DNA was extracted using the DNeasy Tissue Kit (Qiagen) following manufacturer's guidelines. Amplification by PCR was done using the primers LCO1490 and HCO2198 (FOLMER et al. 1994) in a $25 \mu \mathrm{l}$ total PCR volume containing $15.4 \mu \mathrm{l}$ of purified water, $2.5 \mu \mathrm{l}$ of $10 \mathrm{x}$ NH4-based Reaction Buffer, $1.5 \mu \mathrm{l}$ of $\mathrm{MgCl}_{2}(3 \mathrm{mM}), 2 \mu \mathrm{l}$ of $10 \mathrm{mM}$ dNTP $(2.5 \mathrm{mM}$ each), $0.5 \mu \mathrm{l}$ of BSA, $1 \mu \mathrm{l}$ of each primer $(10 \mu \mathrm{M}), 0.1 \mu \mathrm{l}$ of BIOTAQ $^{\mathrm{TM}}$ DNA Polymerase, and $1 \mu \mathrm{l}$ of DNA extract. The PCR was executed with the following protocol: initial denaturing step at $95^{\circ} \mathrm{C}$ for 2 minutes, 40 amplification cycles $\left(94^{\circ} \mathrm{C}\right.$ for 30 seconds, $46^{\circ} \mathrm{C}$ for 35 seconds, $72^{\circ} \mathrm{C}$ for 45 seconds), and a final step at $72^{\circ} \mathrm{C}$ for 5 minutes. PCR success was checked by running products on a $1 \%$ TAE agarose gel, and successfully amplified products were cleaned following EXO I/rAP PCR cleanup protocol and outsourced for DNA sequencing by Macrogen inc. (https://dna.macrogen.com).

Phylogenetic analyses. To identify the genera closest to Barretonus among taxa with available COI sequences in public repositories, all available $C O I$ barcode sequences of Cossoninae were first retrieved from GenBank (search for 'Cossoninae \& COI' on $12^{\text {th }}$ February 2019 at https:// www.ncbi.nlm.nih.gov/genbank/). After excluding sequences that did not cover the 5' barcode region, a total of 105 sequences, representing approximately 40 species from 17 genera were retained, and then aligned with the newly generated Barretonus sequences from the Canary Islands 
Table 1. Specimens of the genus Barretonus used in the genetic study. GenBank accession numbers for additional taxa are shown in Figure 1.

\begin{tabular}{llll}
\hline Species & Voucher & Locality & $\begin{array}{l}\text { Accession } \\
\text { number }\end{array}$ \\
\hline Barretonus auarita sp. nov. & SCI1311 & Juan Adalid, La Palma, R. García leg. & MN245568 \\
& BC00068 & Playa de Nogales, LaPalma, J. Krátký leg. & MN245569 \\
Barretonus daute sp. nov. & SCI234 & Los Silos, Tenerife, GEEI leg. & MN245563 \\
& SCI235 & Los Silos, Tenerife, GEEI leg. & MN245566 \\
& SCI236 & Los Silos, Tenerife, GEEI leg. & MN245564 \\
& SCI228 & Los Silos, Tenerife, GEEI leg. & MN245565 \\
& SCI227 & Los Silos, Tenerife, GEEI leg. & MN245567 \\
& - & Madeira & FJ716582 \\
Barretonus minor & * Island Ecology and Evolution Research Group (Grupo de Ecología y Evolución en Islas), of the Instituto de \\
Productos Naturales y Agrobiología (CSIC).
\end{tabular}

using the MAFFT E-INS-I algorithm (КАTOH et al. 2002). A preliminary maximum likelihood tree was generated using the Fast Tree 2.1.5 (Price et al. 2009) tool in Geneious 7.1.9 (KeARSE et al. 2012) to identify taxa closely related to Barretonus, yielding a data set including: (i) Barretonus representatives from the Canary Islands (Table 1); (ii) $B$. minor from Madeira; (iii) representatives of the genera Caulotrupis Wollaston, 1854, Pselactus Broun, 1886 and Pseudophloeophagus, which were revealed as the taxa closest to Barretonus with available $C O I$ sequences (there were no sequences available for Leipommata). Representatives of the genera Stereocorynes Wollaston, 1873 and Pentarthrum Wollaston, 1854 were included as outgroups.

The final dataset included 38 sequences representing 16 known species from six genera. ModelFinder (KaLYAANAMOORTHY et al. 2017) was used to estimate the best codon partitioning scheme and best-fitting substitution model for the dataset, which were used for subsequent analyses. The favoured partition scheme and substitution model included two partitions: (i) $1^{\text {st }}$ and $2^{\text {nd }}$ codon position combined, with a TIM2e $+\mathrm{G}$ model, and (ii) $3^{\text {rd }}$ codon position with a $\mathrm{TN}+\mathrm{G}$. Phylogenetic maximum likelihood inferences were made with IQTree 1.5.5 (NGUYEN et al. 2015) on the IQ-TREE web server at http://iqtree.cibiv.univie.ac.at (TRIFINOPOuLOS et al. 2016). Nodal support was obtained by 1000 ultrafast bootstrap (UFBoot) replicates (MinH et al. 2013).

In addition, we used Bayesian phylogenetic analyses in BEAST 1.8 (DRUMmond et al. 2012) to simultaneously estimate an ultrametric phylogenetic tree and ages of divergence. We used the rates of molecular evolution obtained for the same DNA fragment for the genus Carabus (Coleoptera, Carabidae) (ANDÚJAR et al. 2012, 2014) as calibration priors. A uniform function prior on the mean substitution rate was applied with maximum and minimum bounds ( 0.0198 and 0.01 substitutions per site per million years per lineage, respectively) matching the $95 \%$ confidence interval of the rates obtained by ANDÚJAR et al. (2012). Two independent runs were conducted. Analyses were performed applying the favoured partition scheme and models of substitutions, but using a SYM model instead the TIM2e. In the molecular clock settings, codon partitions were not considered. An uncorrelated lognormal clock and a Yule speciation prior on the tree were applied, and analyses were run for 10 million generations sampling one tree every 1000 generations. A consensus tree was estimated with TreeAnnotator (DRUMMOND et al. 2012) discarding the first $50 \%$ of trees as a burn-in fraction and combining sampled trees from the two independent runs, after checking ESS of likelihood, evolutionary rates and root age values, and ensuring that the tree likelihood values had reached a plateau. Posterior probabilities were considered a measure of node support. All BEAST analyses were done on the CIPRES portal (MILLER et al. 2010).

\section{Results and discussion}

Detailed morphological analysis of male and female specimens from three populations in the Canary Islands shows: (i) clear differences between the Canarian populations and the species from the Madeira archipelago; (ii) no clear differences between specimens from Juan Adalid and Playa de Nogales, two localities in the same island of La Palma separated by $18 \mathrm{~km}$, and; (iii) appreciable differences between specimens from La Palma and those from Tenerife, comparable to inter-species differences described among the other species of the genus (FolWACZNY 1972, 1975) and among species of related genera such as Caulotrupis (STÜBen \& SCHÜTTE 2018).

Analyses based on both maximum likelihood (ML) and Bayesian inference were fully consistent, with differences only affecting non-supported nodes; all analyses recovered a monophyletic Barretonus (Bayesian $\mathrm{pp}=1$, ML bootstrap $=100$ ), including representatives of the three Canarian populations and B. minor from Madeira. Barretonus + Caulotrupis + Pselactus + Pseudophoeophagus formed a well-supported clade (Bayesian pp $=0.96$, ML bootstrap $=85$ ) with uncertain internal topology in BI analysis and a moderate support of the sister relationship between Barretonus and Caulotrupis in ML analysis (ML bootstrap = 74). Bayesian analyses recovered the monophyly of the genus Caulotrupis and the genus Pselactus, although with low support.

Internal relationships among Barretonus populations were not resolved with support and varied among analyses. Considering the topology and ages recovered with Bayesian inference, dating showed that the split of $B$. minor (Madeira) and the Canarian populations occurred around 1.84 million years ago (Mya) (95\% HPD interval 3.14-0.97 Mya) and diversification of the Canarian populations dated between 1.39 and 1.14 Mya (95\% HPD interval $2.38-0.52 \mathrm{Mya}$ ). This result is fully compatible with the emergence of the island of La Palma approximately 
A

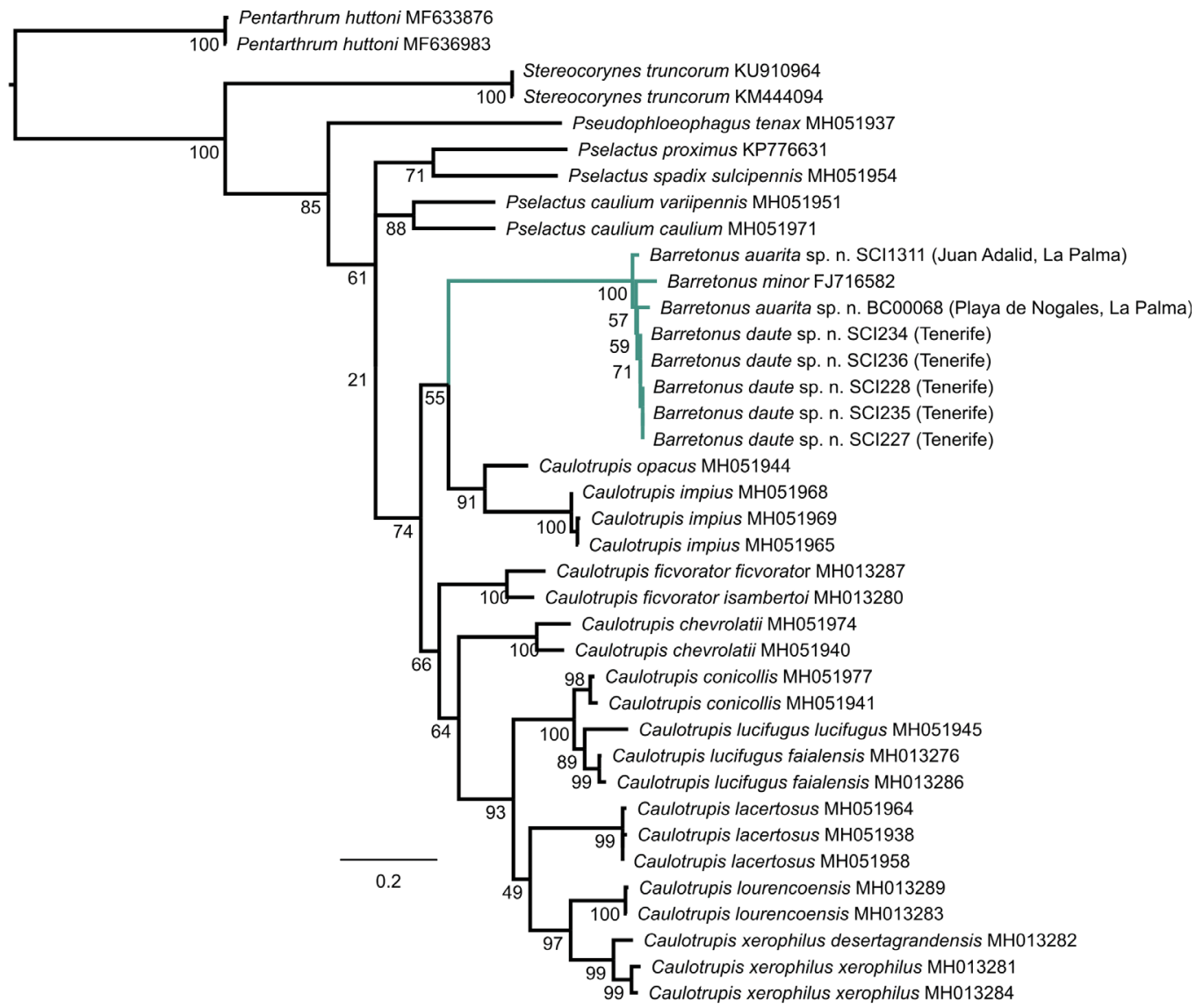

B

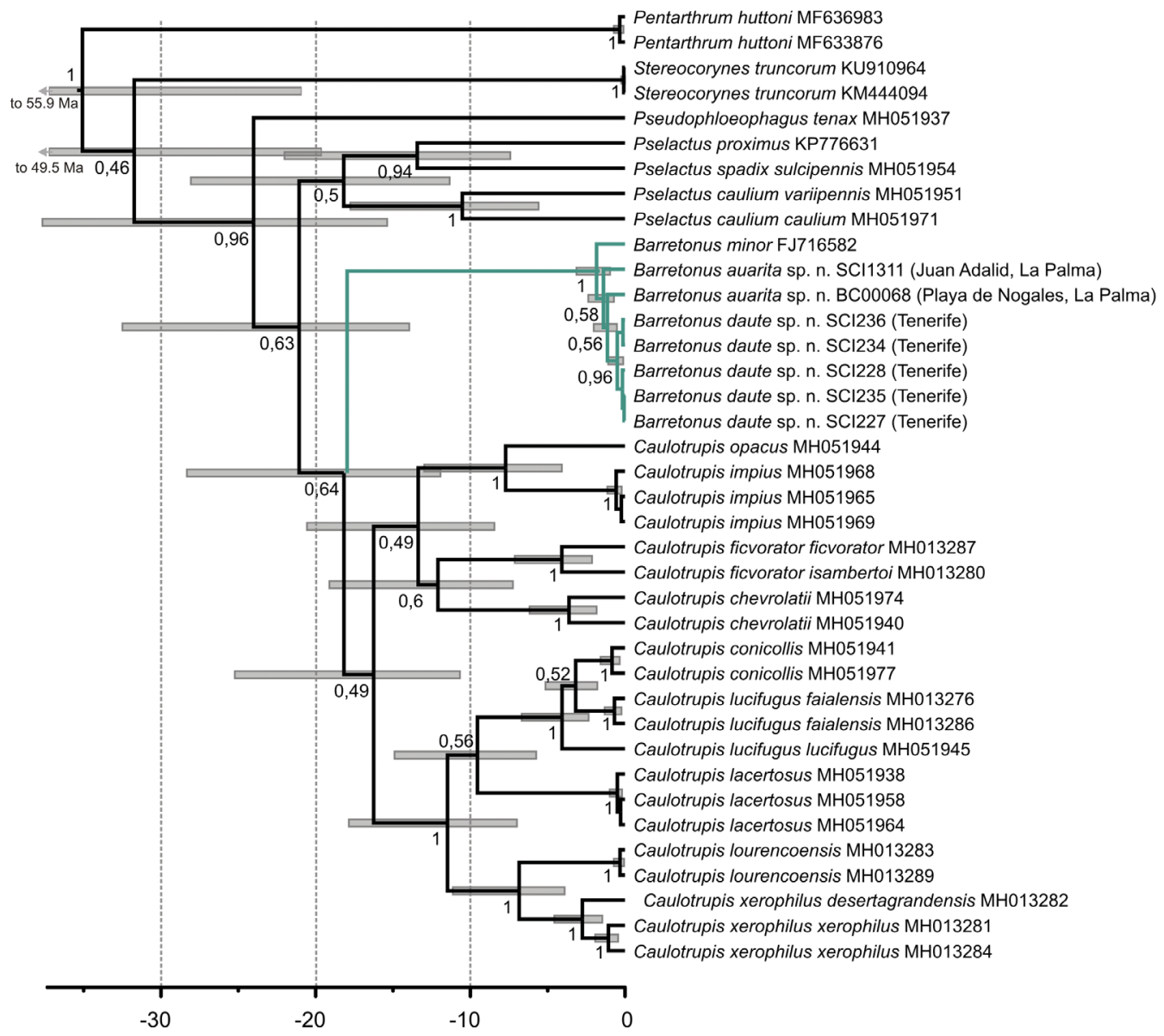

Fig. 1. Maximum likelihood tree obtained from IQTree (A) and Bayesian dated tree obtained in BEAST with scale axis representing Ma (B). Grey bars represent the 95\% HPD interval of node dated ages. Numbers on nodes indicate ML bootstrap values and posterior probabilities respectively. Codes on names indicate voucher numbers or Genbank Accession numbers. 
A

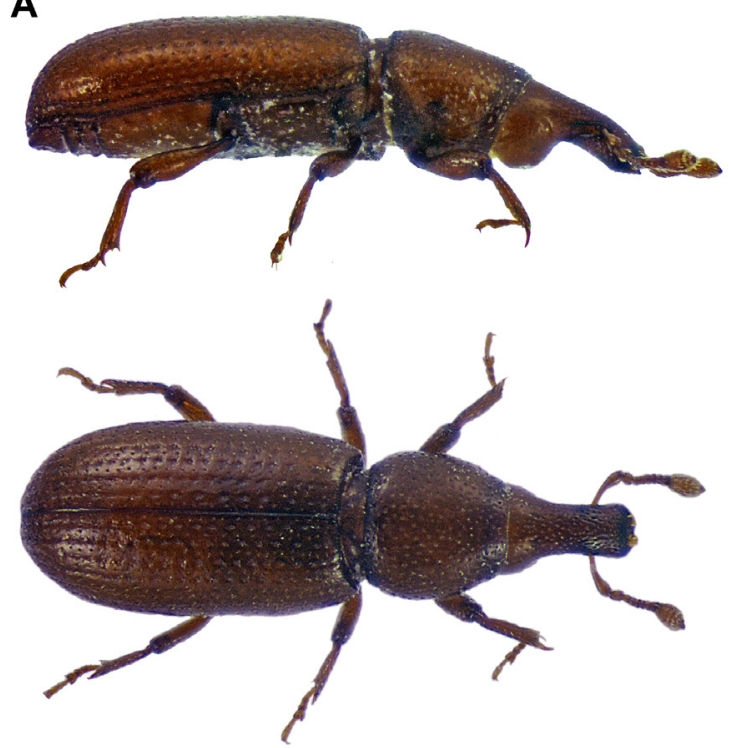

B

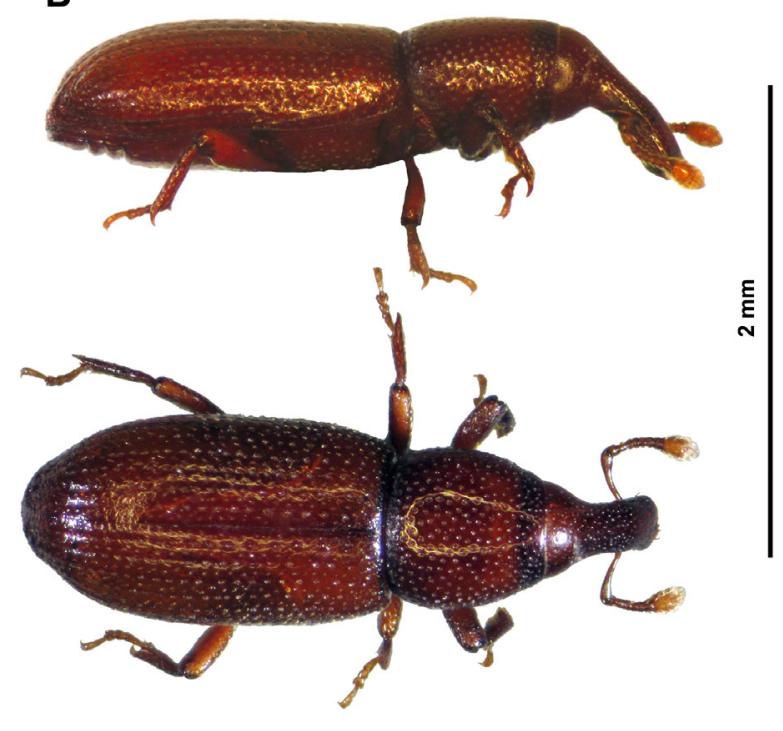

Fig. 2. Dorsal and lateral habitus: A - Barretonus auarita sp. nov.; B - B. daute sp. nov.

2 Mya (AnCocheA et al. 1994). The relationships among the three Canarian populations showed a trend for a closer relationship between the populations from Tenerife and Playa Nogales in La Palma in BEAST analysis, although this relationship is not supported by posterior probability. In fact, the sequences of the population from Tenerife show exactly the same number of differences $(n=12$; non corrected divergence $\approx 2.0 \%$; GTR corrected divergence $\approx 2.4 \%$ ) from the two populations in La Palma, despite the latter two showing more differences between them (n $=19$; non corrected divergence $=3.2 \%$; GTR corrected divergence $=3.8 \%$ ). Despite this, morphology shows no differences between the two populations in La Palma, which both show several differences from the population of Tenerife (Table 2). This result leaves open several hypotheses for the evolution of the group, including (i) an independent colonization of Tenerife and La Palma by specimens from Madeira through different events; (ii) colonization of one island firstly from Madeira, with a subsequent dispersal to the other island; or even (iii) colonization of Madeira from the Canary Islands. The last scenario seems less probable given that the sea current, i.e. the marine dispersal vector for drifting materials, runs from NE to SW, i.e. from Madeira to the Canaries, and not in the reverse. Regarding these hypotheses, and considering the endogean status of Barretonus species, we suggest that mega-landslides could have had an important role in promoting the dispersal of the lineage at least from Tenerife to La Palma, as it has been demonstrated for other beetles inhabiting the same islands (GARCÍA-OLIVARES et al. 2017). It has been documented that several mega-landslides occurred in both Tenerife and La Palma between 2 and 0.5 Mya (CARracedo et al. 2009). Additional molecular data including unsampled populations and species, and with additional molecular markers, is needed for a better understanding of the evolutionary history of the lineage.
Both the non-supported genetic relationships within Barretonus, and the relatively recent estimated ages of the species diversification are compatible with incomplete lineage sorting after relatively recent colonisation events within the last 1-2 million years. Based on clear morphological differences between specimens from La Palma and Tenerife, we describe below two new species: Barretonus auarita sp. nov. from La Palma and B. daute sp. nov. from Tenerife.

\section{Taxonomic acts}

Both species from the Canary Islands described below can be differentiated from Barretonus species from Madeira by body size proportionally smaller (especially in males), rostra narrower, pronota more oval, shoulders less prominent, integuments smoother and shinier, microsculpture less visible, and body pubescence shorter (Fig. 4).

\section{Barretonus auarita García \& Oromí, sp. nov. (Figs 2, 3A-G)}

Type locality. Juan Adalid, Garafía, La Palma, Canary Islands (70 m a.s.l., $\left.28^{\circ} 51^{\prime} 14.44^{\prime \prime} \mathrm{N}, 17^{\circ} 54^{\prime} 25.43^{\prime \prime} \mathrm{W}\right)$.

Type material. HоLотуре: 1 , Juan Adalid, Garafía, La Palma, Canary Islands ( $70 \mathrm{~m}$ a.s.1., $\left.28^{\circ} 51^{\prime} 14.44^{\prime \prime} \mathrm{N}, 17^{\circ} 54^{\prime} 25.43^{\prime \prime} \mathrm{W}\right), 3.1 .2018$, sieving Euphorbia balsamifera, R. García leg (DZUL). ParatyPes: 40 spec. from the same locality as the holotype: $2+\circ, 20 . v .1992$, R. García leg.;

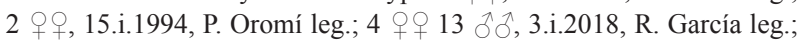
14 우 5 ô, 15.v.2018, R. García leg. Depositories: AMC (1 1 \& 1 ),

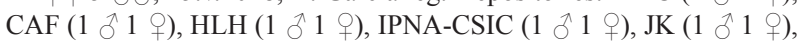

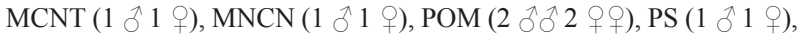
RGB (10 के के 10 우 $)$.

Additional material examined. La Palma, El Granel, Playa de Nogales, 3 spec. (1 1 and 1 spec.), 16.iii.2018, sieving Crithmum maritimum, J. Krátký leg.

Description. Male. Total length (including rostrum) 2.45-2.90 mm. Maximal width 0.73-0.93 mm. Body yellowish-brown, vestiture glabrous, with tiny setae (2 $\mu \mathrm{m})$, more visible on elytral striae, interstriae and edges 


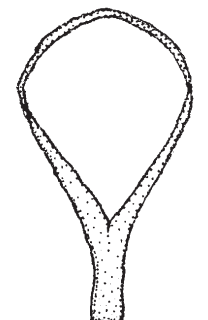

A

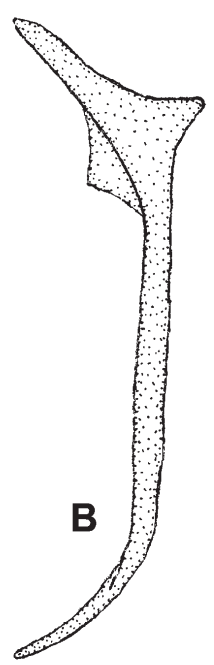

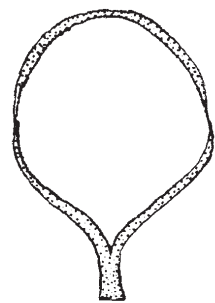

$A^{*}$

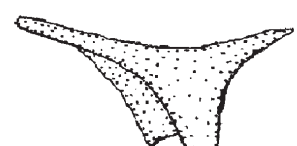

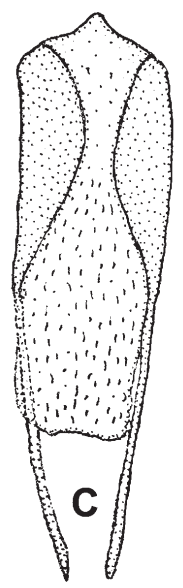
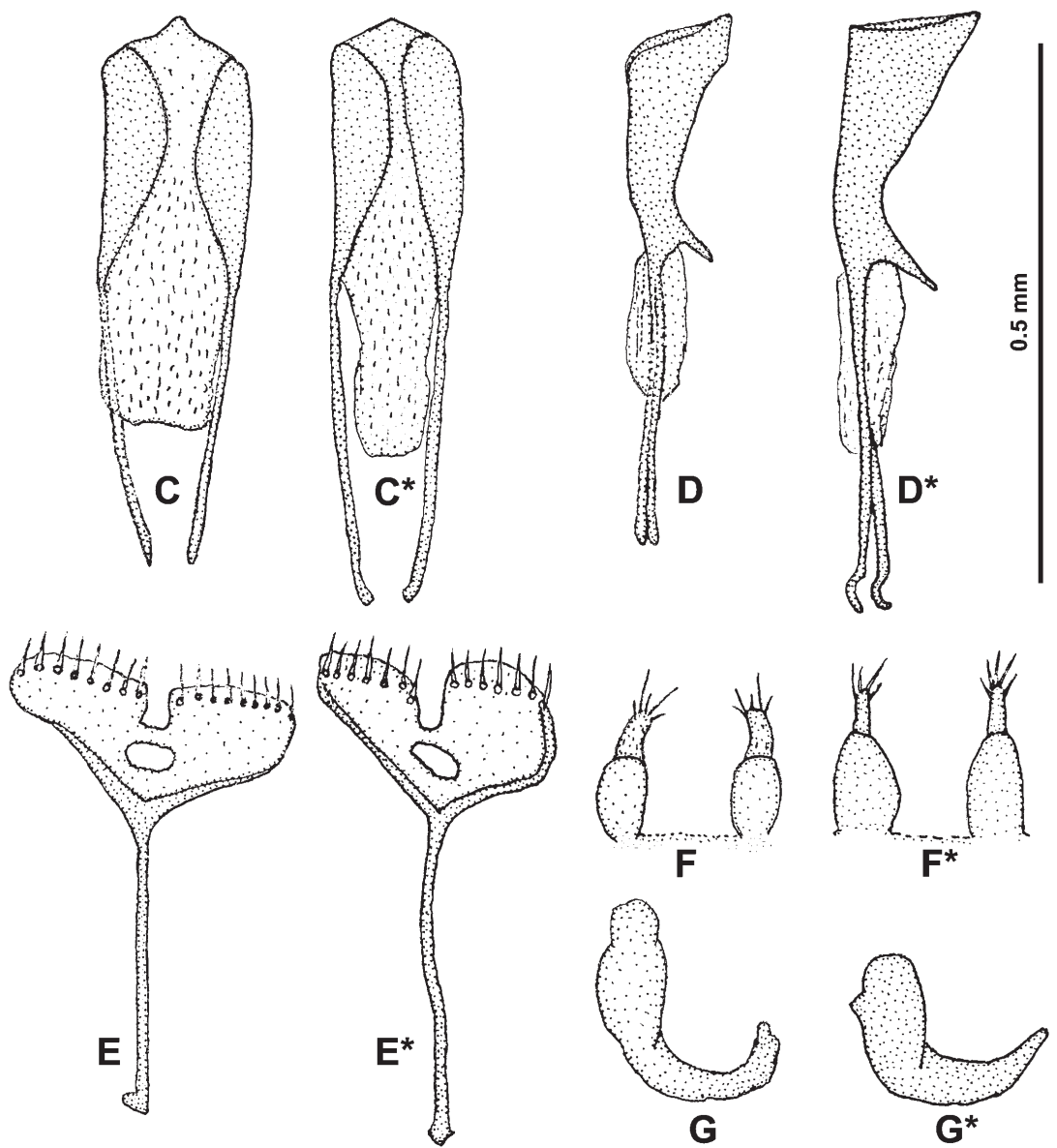

Fig. 3. Structures of the genitalia of males and females of B. auarita sp. nov. (letters without asterisks) and B. daute sp. nov. (letters with asterisks): A tegmen. $\mathrm{B}$ - spiculum gastrale. $\mathrm{C}-\mathrm{D}$ - aedeagus in dorsal and lateral view. $\mathrm{E}$ - spiculum ventrale. $\mathrm{F}$ - ovipositor. $\mathrm{G}$ - spermatheca.

of pronotum, setae longer on rostral apex, antennae and legs. Apterous.

Head sphero-conical, short, completely lacking eyes.

Rostrum (average length $0.44 \mathrm{~mm}$ ), $0.64 \times$ as long as pronotum and $1.8 \times$ as long as its width at apex, with punctures and some setae; slightly curved in lateral view, dorsally with slightly concave sides in middle. Rostral surface and punctation similar to that on frons, the latter sometimes with small fovea; posterior part of rostrum convex in lateral view. Ventrally with two rows of punctures in middle zone and with two fine carinae converging towards base of rostrum.

Antennae pubescent; scape curved, widest in apical third, $4.5 \times$ as long as its maximum width and $0.85 \times$ as long as funicle. First funicular antennomere longest, cylindroconical, $1.25 \times$ as long as wide, funicular antennomeres 3 to 7 tronco-conical and transverse, narrower 2. Antennal club oval, $1.9 \times$ as long as wide and as long as antennomeres 6-7 combined.

Pronotum isodiametric, with slightly convex sides, widest in $1 / 3$ of base, anterior edge $0.76 \times$ narrower than basal edge. Surface smooth and shiny, except on basal edge and lateral margins; with strong round punctures separated by $1 \times$ their diameter, punctures smaller and closely located at apices.
Scutellum not visible.

Pterothorax with elytra subparallel, base slightly concave and wider than pronotum, sometimes slightly sinuous in middle; $2.3 \times$ as long as pronotum and $1.86 \times$ as long as wide; striae composed of well marked but shallow punctures; interstriae on disc flat and slightly convex towards apical declivity, the latter short and steep with small aligned punctures. Metaventrite $2 \times$ as wide as long, slightly depressed on disc, with strong longitudinal furrow in apical zone.

Abdomen ventrally with microreticulated surface and round punctures separated by $2 \times$ their diameter. First two ventrites with convex disc, punctures more separated between them; fifth ventrite $2.25 \times$ as wide as long, with similar punctation as that on first two ventrites.

Legs with smooth, shiny surface and well defined punctation, covered by dispersed setae. Procoxae separated by $1.1 \times$ their diameter from anterior margin of pronotum and $0.15 \times$ their diameter from the posterior margin of pronotum; separated between each other by $0.14 \times$ procoxal diameter. Mesocoxae $2 \times$ their diameter apart. Pro-, meso- and metafemora respectively $3.3 \times, 3.1 \times$ and $3.7 \times$ as long as wide. Protibiae $3.25 \times$ as long as wide at apex (without counting uncus), almost straight, with external edge smooth and with dense strip of setae in slight inner apical notch. Meso- and metatibiae $3.53 \times$ and $4.3 \times$, respectively, as long as wide. 
First tarsomere $2.5 \times$ longer than wide; second tarsomere isodiametric; third strongly bilobed and isodiametric; onychium $3.3 \times$ as long as wide.

Aedeagus. Tegmen without parameroid lobes and with short manubrium (Fig. 3A). Spiculum gastrale robust, with asymmetric arms, shorter arm less than half length of longer, longer arm with external lamella and shaft bent distally (Fig. 3B). Penis roughly symmetric in dorsal view, apex broadly triangular and briefly pointed, laterally with one side concave and the other one convex; slightly curved in lateral view, with acute apex and small callus; dorsal plate incomplete; internal sac with densely arranged teeth in apical third of tube (Figs 3C-D).

Female. Very similar to male, total length $2.15-2.6 \mathrm{~mm}$, maximal width $0.75-0.86 \mathrm{~mm}$. Rostrum $2.44 \times$ as long as wide. Scape $3.7 \times$ as long as wide, widening from middle; funicular antennomeres 6 and 7 wider than 1 . Elytra $2.32 \times$ as long as pronotum, $1.64 \times$ as long as wide. $5^{\text {th }}$ ventrite $2.83 \times$ as wide as long. Pro-, meso- and metafemora respectively $3.1 \times$, $3 \times$ and $3.4 \times$ as long as wide. Pro-, meso- and metatibiae respectively $3.2 \times, 3.1 \times$ and $3.4 \times$ as long as wide.

Ovipositor with conical apical styles, bearing 4-5 macrosetae (Fig. 3F). Spiculum ventrale bilobed bearing about 17 macrosetae (Fig. 3E); manubrium long, straight, with small unilateral termination. Spermatheca narrow, with curved cornu and hardly developed glandular lobe (Fig. 3G).

Differential diagnosis. For comparison with $B$. daute sp. nov., see Table 2.

Etymology. The specific epithet auarita refers to the auaritas, the aboriginal people inhabiting La Palma before the colonization by Europeans. Noun in apposition.

Biology and ecology. All specimens from Juan Adalid were collected at about $20 \mathrm{~m}$ a.s.1., in a partially well preserved coastal scrub (Euphorbia balsamifera Aiton) with northern orientation. The first specimens collected were four females in the 1990s, found inside the dead roots of E. balsamifera. The same site was subsequently visited on numerous occasions in search for males to describe this new species, but with no success. The largest series was obtained recently by screening decaying roots of E. balsamifera. One of the specimens was immature and collected inside its pupal chamber, so at least we know where larvae of this species develop and that the nutritious plant certainly is Euphorbia balsamifera. In comparison, samples from Playa de Nogales were collected recently by sifting decaying litter of Crithmum maritimum, a plant where other endogean curculionids such as Styphloderes lindbergi Roudier, 1963 and Madeiran Barretonus were also collected. One of the females from Juan Adalid was dissected, and one oval egg measuring $0.5 \times 0.4 \mathrm{~mm}$ was found inside its abdomen.

\section{Barretonus daute García \& Andújar, sp. nov.}

$$
\text { (Figs 2, 3A*-G*) }
$$

Type locality. Camino Real las Arenas, Canal de Icod, Los Silos, Tenerife, Canary Islands (213 m a.s.1., $28^{\circ} 21^{\prime} 51.77^{\prime \prime} \mathrm{N}, 16^{\circ} 48^{\prime} 4.44^{\prime \prime} \mathrm{W}$ ).

Type material. Holotype: 1 of, Camino Real las Arenas, Canal de Icod, Los Silos, Tenerife, Canary Islands (213 m a.s.1., $28^{\circ} 21^{\prime} 51.77^{\prime \prime} \mathrm{N}$, $16^{\circ} 48^{\prime} 4.44^{\prime \prime}$ W), 10.i.2019, H. López \& D. Suárez leg. (MCNT). ParaTYPES: 13 spec., same data as holotype, 3 o 30 ; same locality as holotype, $2 \hat{0} 4+9$, 1.ix.2017, C. Andújar leg. Canary Islands, Tenerife,
Caleta de Interián (219 m a.s.1., 28 21'51.74"N, 16²47'14.73"W): 1 5.xii.2001, sieving Pistacia atlantica litter, M.A. Peña leg. Depositories:

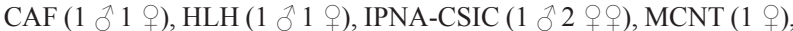

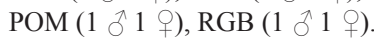

Description. Male. Total length (including rostrum) 2.35-2.75 mm. Maximal width 0.85-1.0 mm. Body dark reddish-brown, vestiture glabrous, with tiny setae (2-3 $\mu \mathrm{m})$, more visible on elytral striae, interstriae and edges of pronotum, setae longer on the rostral apex, antennae and legs. Apterous.

Head sphero-conical, short, with a few ommatidia.

Rostrum (average length $0.38 \mathrm{~mm}$ ), $0.66 \times$ as long as pronotum and $1.7 \times$ as long as its width at apex, with punctures and some setae; slightly curved in lateral view, dorsally with slightly concave sides in middle. Rostral surface and punctation similar to that on frons, the latter slightly depressed and sometimes with small fovea; posterior part of rostrum convex in lateral view. Ventrally with irregular row of punctures in median zone and with two fine carinae converging towards base of rostrum.

Antennae hirsute; scape curved, widest in apical half, $3.5 \times$ as long as its maximum width and $0.75 \times$ as long as funicle. First funicular antennomere longest, cylindro-conical, 1.25× as long as wide, funicular antennomeres 3 to 7 tronco-conical and transverse, 2 narrower. Antennal club oval, $1.9 \times$ as long as wide and as long as antennomeres 6-7 combined.

Pronotum transverse $(0.96 \times$ shorter than wide $)$, with slightly convex sides, widest in $1 / 5$ of the base, anterior edge $0.72 \times$ narrower than basal edge. Surface smooth and shiny, except on basal edge and lateral margins; with strong round punctures separated by $1 \times$ their diameter, punctures smaller and closely located at apices.

Scutellum not visible.

Pterothorax with elytra slightly oblong, base slightly concave and wider than pronotum, sometimes slightly sinuous in middle; $2.3 \times$ as long as pronotum and $1.66 \times$ as long as wide; striae composed of well-marked punctures, slightly shallower towards short steep apical declivity. Interstriae somewhat convex with small punctures; surface rough and shiny, becoming striated towards apex and sides. Metaventrite with microreticulated surface, $1.63 \times$ as wide as long, with large depression on disc and another small one in apical zone.

Abdomen ventrally with shiny surface and round punctures separated by $1 \times$ their diameter. First two ventrites with smooth and shiny surface, with convex disc, punctures finer and more separated between them; fifth ventrite $2.7 \times$ as wide as long, with similar punctation as that on first two ventrites.

Legs with smooth, shiny surface and well-defined punctation, slightly covered by scaly dispersed setae. Procoxae separated by $1.5 \times$ their diameter from anterior margin of pronotum and $0.28 \times$ their diameter from posterior margin of pronotum; separated between each other by $0.14 \times$ procoxal diameter. Mesocoxae $1.4 \times$ their diameter apart. Pro-, meso- and metafemora respectively $3.0 \times, 3.3 \times$ and $4.2 \times$ as long as wide. Protibiae $3.3 \times$ as long as wide at apex (without counting uncus), almost straight, with external edge slightly sinuous and with dense strip of setae in slight 


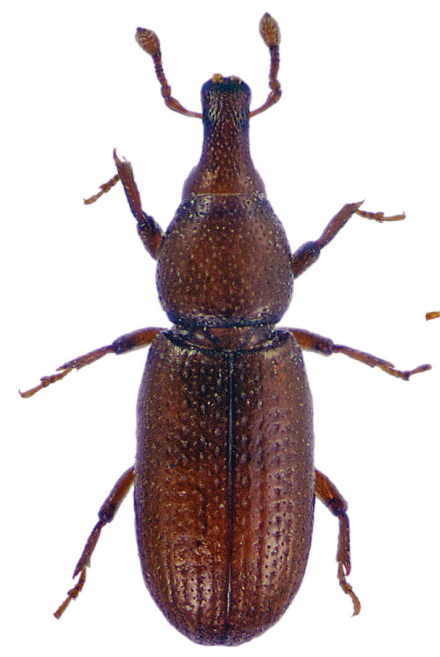

A

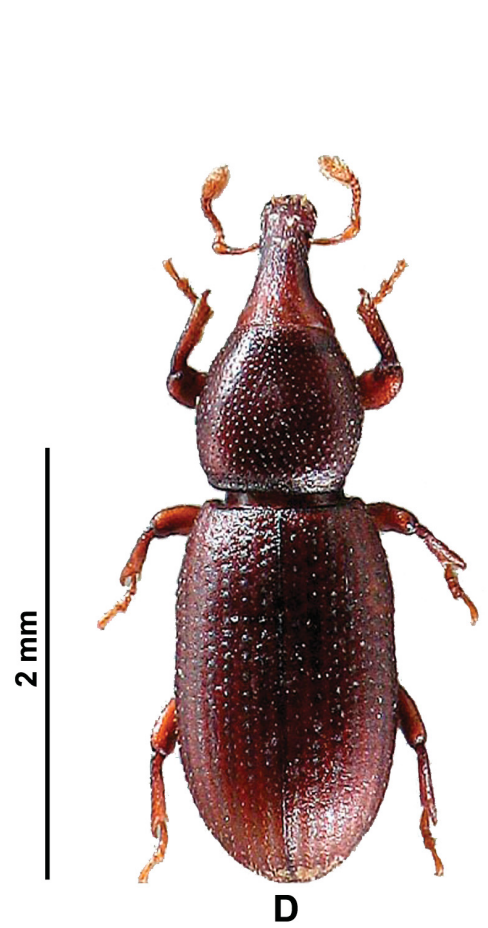

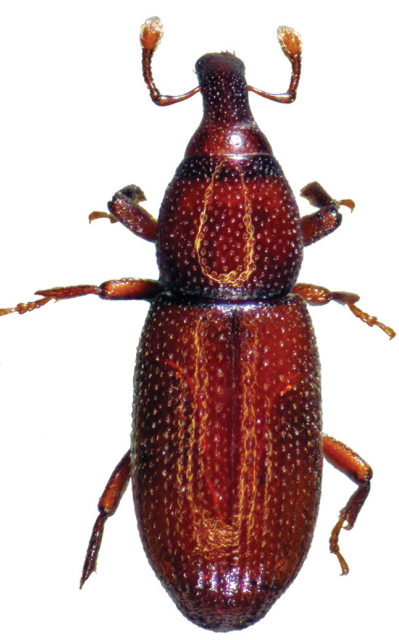

B

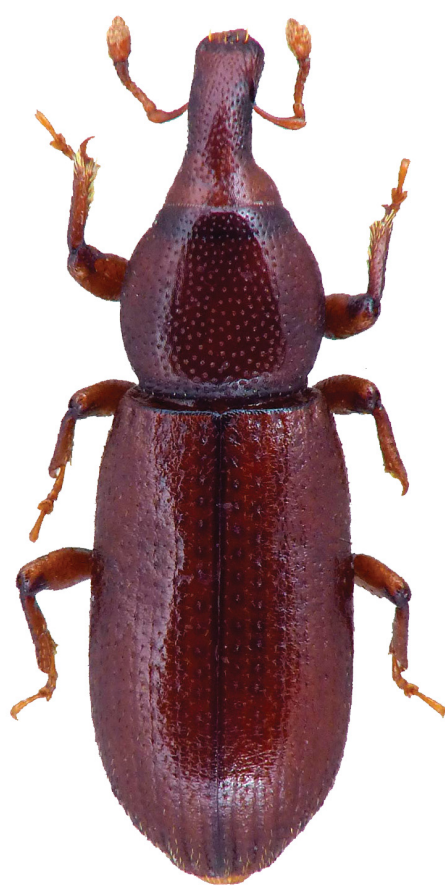

E

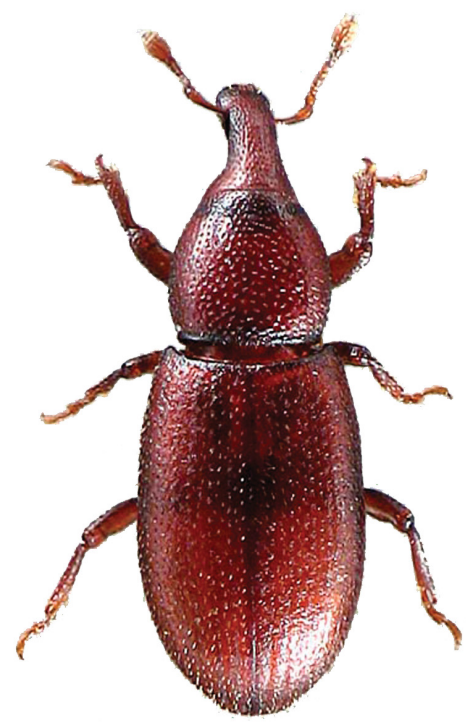

C

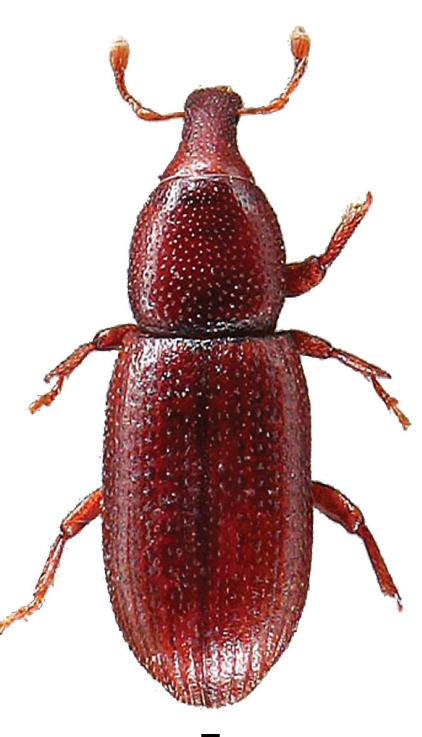

$\mathbf{F}$

Fig. 4. Dorsal view of the known species of Barretonus. A - B. auarita sp. nov. (La Palma); B - B. daute sp. nov. (Tenerife); C - B. minor Folwaczny, 1972 (Porto Santo); D - B. hinterseheri Folwaczny, 1975 (Madeira); E - B. major Folwaczny, 1972 (Ilhéu Chão, Madeira); F - B. desertae Roudier, 1958 (Deserta Grande, Madeira). The photographs of the Madeiran species were taken from https://www.curci.de.

inner apical notch. Meso- and metatibiae $3.6 \times$ and $4.4 \times$, respectively, as long as wide. First tarsomere $2.5 \times$ longer than wide; second tarsomere isodiametric; third strongly bilobed and transverse; onychium approximately $4.2 \times$ as long as wide.

Aedeagus. Tegmen without parameroid lobes and with very short manubrium (Fig. 3A*). Spiculum gastrale robust, with asymmetric arms, shorter arm more than half length of longer, longer arm with external lamella and shaft strongly bent distally (Fig. 3B*). Penis almost symmetric in dorsal view, apex pointed, laterally with one side concave and the other one convex; slightly curved in lateral view, with acute apex; dorsal plate incomplete; internal sac with densely arranged teeth in apical third of tube (Figs $3 \mathrm{C}^{*}-\mathrm{D}^{*}$ ).
Female. Similar to male, total length $2.68-2.82 \mathrm{~mm}$, maximal width $0.75-0.83 \mathrm{~mm}$. Rostrum $2.25 \times$ as long as wide. Scape $4.6 \times$ as long as wide, widening from middle; first funicular antennomere wider than the other antennomeres. Elytra $2.2 \times$ as long as pronotum, $1.62 \times$ as long as wide. $5^{\text {th }}$ ventrite $2.5 \times$ as wide as long. Pro-, meso- and metafemora respectively $2.83 \times, 3.0 \times$ and $3.3 \times$ as long as wide. Pro-, meso- and metatibiae respectively $3.4 \times, 3.7 \times$ and $3.62 \times$ as long as wide.

Ovipositor with cylindrical and narrow apical styles, bearing 4-5 macrosetae (Fig. 3F*). Spiculum ventrale bilobed bearing 14 macrosetae (Fig. 3E*); manubrium long, sinuous, with sagittate tip. Spermatheca with curved cornu and hardly developed glandular lobe (Fig. 3G*). 
Table 2. Comparative morphological characters in the two new species of Barretonus.

\begin{tabular}{|c|c|c|}
\hline & Barretonus auarita sp. nov. & Barretonus daute sp. nov. \\
\hline Body & Females $2.15-2.60 \mathrm{~mm}$ long. & Females $2.68-2.82 \mathrm{~mm}$ long. \\
\hline Eyes & Completely absent. & With a few ommatidia. \\
\hline Scape & $\begin{array}{l}\text { Male: widest in apical third, } 4.5 \times \text { as long as its } \\
\text { maximum width and } 0.85 \times \text { as long as the funicle. } \\
\text { Female: } 3.7 \times \text { as long as its maximum width. }\end{array}$ & $\begin{array}{l}\text { Male: widest in apical half, } 3.5 \times \text { as long as its } \\
\text { maximum width and } 0.75 \times \text { as long as the funicle. } \\
\text { Female: } 4.6 \times \text { as long as its maximum width. }\end{array}$ \\
\hline Pronotum & Isodiametric, with maximum width in basal third. & $\begin{array}{l}\text { Transverse }(0.96 \times \text { as long as wide }) \text {, with maximum } \\
\text { width in basal fifth. }\end{array}$ \\
\hline Elytra & $1.86 \times$ as long as wide in male, $1.64 \times$ in female. & $1.66 \times$ as long as wide in male, $1.62 \times$ in female. \\
\hline Onychium & $3.3 \times$ as long as wide. & $4.2 \times$ as long as wide. \\
\hline Aedeagus & $\begin{array}{l}\text { Manubrium short; spiculum gastrale with asymmet- } \\
\text { ric arms, the shorter arm less than half the length of } \\
\text { the longer; penis with a small apical callus. }\end{array}$ & $\begin{array}{l}\text { Manubrium very short; spiculum gastrale with } \\
\text { asymmetric arms, the shorter arm more than half } \\
\text { the length of the longer; penis without apical callus. }\end{array}$ \\
\hline Ovipositor & $\begin{array}{l}\text { Apical styles conical; manubrium straight, with a } \\
\text { small unilateral termination. }\end{array}$ & $\begin{array}{l}\text { Apical styles cylindrical and narrow; manubrium } \\
\text { sinuous, with sagittate tip. }\end{array}$ \\
\hline
\end{tabular}

Differential diagnosis. For comparison with $B$. auarita sp. nov., see Table 2.

Etymology. The specific epithet daute is the name of the 'menceyato' of Daute, the westernmost of the nine kingdoms in which the ancient inhabitants of Tenerife, the Guanches, had divided the island. This is the geographical area where this new species was found. Noun in apposition. Biology and ecology. All specimens were collected in the municipality of Los Silos at about $213 \mathrm{~m}$ a.s.l., in an area known as Camino Real las Arenas, with northwest orientation, partially dominated by well preserved thermo-sclerophyllous vegetation. The specimens were obtained from two soil samples taken to a depth of $20 \mathrm{~cm}$ and from two litter-screening samples (one from under a Phoenix canariensis palm and the other one under a Pistacia atlantica tree). Both soil and litter samples were washed to refloat the organic matter for later extraction of fauna in Berlese funnels (see ARRIBAs et al. 2016, for details).

\section{Conclusions}

Detailed morphological analysis points to the existence of at least two sister species of Barretonus in the Canary Islands, with DNA sequence data of the mitochondrial COI gene suggesting a recent origin. Specimens from Playa de Nogales in La Palma are morphologically similar to $B$. auarita, but show a relatively high genetic distance from it; thus, these specimens are here conservatively identified as $B$. auarita but not included in the type series, waiting for additional data (e.g., sequencing of additional specimens from the same and new populations) for a more robust evaluation of the potentially genetically differentiated lineages inferred from our limited sampling. Our results reveal that the genus Barretonus is composed of six anophthalmous or microphthalmous species with an endogean lifestyle, and the genus remains a Macaronesian endemic distributed across the Madeira Archipelago and in the Canary Islands.

\section{Acknowledgements}

We thank Jiří Krátký for the loan of three specimens of Barretonus auarita collected in La Palma, Miguel Ángel
Peña Estévez for the loan of one specimen of Barretonus daute from Tenerife, and Peter E. Stüben for the loan of specimens of the Madeiran species. Daniel Suárez helped us with the field work. Guido Jones revised the English of an earlier version of the manuscript. This study was partly supported by the Spanish Ministry of Sciences (MINECO) (CGL2015-74178-JIN and CGL2017-85718-P).

\section{References}

ANCOCHEA E., HERNÁN F., CENDRERO A., CANTAGREL J., FÚSTER J., IBARROLA E. \& COELLO J. 1994: Constructive and destructive episodes in the building of a young oceanic island, La Palma, Canary Islands, and genesis of the Caldera de Taburiente. Journal of Volcanology and Geothermal Research 60: 243-262.

ANDÚJAR C., SERRANO J. \& GÓMEZ-ZURITA J. 2012: Winding up the molecular clock in the genus Carabus (Coleoptera: Carabidae): assessment of methodological decisions on rate and node age estimation. BMC Evolutionary Biology 12(1)(40): 1-17.

ANDÚJAR C., SORIA-CARRASCO V., SERRANO J. \& GÓMEZZURITA J. 2014: Congruence test of molecular clock calibration hypotheses based on Bayes factor comparisons. Methods in Ecology and Evolution 5: 226-242.

ARRIBAS P., ANDÚJAR C., HOPKINS K., SHEPHERD M. \& VOGLER A. P. 2016: Metabarcoding and mitochondrial metagenomics of endogean arthropods to unveil the mesofauna of the soil. Methods in Ecology and Evolution 7: 1071-1081.

CARRACEDO J. C., PÉREZ TORRADO F. J., PARIS R. \& RODRÍGUEZ BADIOLA E. 2009: Megalandslides in the Canary Islands. Enseñanza de las Ciencias de la Tierra 17(1): 44-56.

DRUMMOND A. J., SUCHARD M. A., XIE D. \& RAMBAUT A. 2012: Bayesian phylogeneticswith BEAUti and the BEAST 1.7. Molecular Biology and Evolution 29: 1969-1973.

FOLMER O., BLACK M., HOEH W., LUTZ R. \& VRIJENHOEK R. 1994: DNA primers for amplification of mitochondrial cytochrome c oxidase subunit I from diverse metazoan invertebrates. Molecular Marine Biology and Biotechnology 3: 294-299.

FOLWACZNY B. 1972: Neue palaearktische Cossoninen. Entomologische Blätter 68(2): 91-96.

FOLWACZNY B. 1975: Barretonus major Folw. ssp. hinterseheri n. ssp. aus Madeira. Entomologische Blätter 71(3): 153-154.

GARCÍA-OLIVARES V., LÓPEZ H., PATIÑO J., ALVAREZ N., MACHADO A., CARRACEDO J. C., SOLER V. \& EMERSON B. C. 2017: Evidence for mega-landslides as drivers of island colonization. Journal of Biogeography 44(5): 1053-1064.

HEBERT P. D. N., CYWINSKA A., BALL S. L. \& DEWAARD J. R. 2003: Biological identifications through DNA barcodes. Proceedings of the Royal Society of London B 270: 313-321. 
KALYAANAMOORTHY S., MINH B. Q., WONG T. K. F., VON HAESELER A. \& JERMIIN L. S. 2017: ModelFinder: fast model selection for accurate phylogenetic estimates. Nature Methods 14: 587-589.

KATOH K., MISAWA K., KUMA K. \& MIYATA T. 2002: MAFFT: A novel method for rapid multiple sequence alignment based on fast Fourier transform. Nucleic Acids Research 30: 3059-3066.

KEARSE M., MOIR R., WILSON A., STONES-HAVAS S., CHEUNG M., STURROCK S., BUXTON S., COOPER A., MARKOWITZ S., DURAN C., THIERER T., ASHTON B., MENTJIES P. \& DRUMMOND A. 2012: Geneious Basic: an integrated and extendable desktop software platform for the organization and analysis of sequence data. Bioinformatics 28: 1647-1649.

MINH B. Q., NGUYEN M. A. T. \& VON HAESELER A. 2013: Ultrafast approximation for phylogenetic bootstrap. Molecular Biology and Evolution 30: 1188-1195.

MILLER M., PFEIFFER W. \& SCHWARTZ T. 2010: Creating the CIPRES Science Gateway for inference of large phylogenetic trees. Proceedings of the Gateway Computing Environments Workshop (GCE) New Orleans, Institute of Electrical and Electronics Engineers (IEEE), New York], pp 1-8.

NGUYEN L. T., SCHMIDT H. A., VON HAESELER A. \& MINH B. Q. 2015: IQ-TREE: a fast and effective stochastic algorithm for estimating maximum-likelihood phylogenies. Molecular Biology and Evolution 32: 268-274.
OSELLA G. 1978: Due nuovi Cossoninae delle Isole Salvages (Coleoptera: Curculionidae) (XVIII contributo alla conoscenza della curculionidofauna endogea). Pp 159-170. In: Contribución al estudio de la historia natural de las Islas Salvajes. Resultados de la expedición cientifica ,Agamenón 76 ' (23 de febrero - 3 de marzo de 1976). Aula de Cultura de Tenerife, Museo de Ciencias Naturales del Cabildo Insular de Santa Cruz de Tenerife, Santa Cruz de Tenerife, 209 pp.

PRICE M. N., DEHAL P. S. \& ARKIN A. P. 2009: FastTree: Computing Large Minimum-Evolution Trees with Profiles instead of a Distance Matrix. Molecular Biology and Evolution 26: 1641-1650.

ROUDIER A. 1958: Curculionides de l'Archipel de Madère. Revue Française d'Entomologie 25: 199-214.

STÜBEN P. 2018: The Macaronesian Islands - an Encyclopedia of Curculionoidea (Coleoptera). [01/06/2018]. < https://www.curci.de >.

STÜBEN P \& SCHÜTTE A. 2018: Revision of the genus Caulotrupis from Macaronesian Islands (Coleoptera: Curculionidae: Cossoninae). Snudebiller: Studies on Taxonomy, Biology and Ecology of Curculionoidea 19(272): 1-38.

TRIFINOPOULOS J., NGUYEN L. T., VON HAESELER A. \& MINH B. Q. 2016: W-IQ-TREE: a fast online phylogenetic tool for maximum likelihood analysis. Nucleic Acids Research 44(W1): W232-W235. 